\title{
Affects Of Globalization and Limitations of Corporate Social Responsibility in India
}

\author{
SP. Harish, SP. Santhosh \\ MS Public Relations \\ M.Tech, CNIS
}

\begin{abstract}
Every corporation has a policy concerning CSR and produces a report annually detailing its activity. Measurement and Evaluation of performance while giving flexibility for an organization to consider its own socially and environmentally significant factors and plan accordingly without being compared favorably or unfavorable with organizations with different priorities. Globalization affects the economy, business life, society and environment in different ways, and almost all corporations have been affected by these changes. In this paper therefore we will consider aspects of this in the context of the objectives of the firm and its procedures for governance. Governance also is an integral part of this process. So business life needs more regulation and proper and socially responsible behavior than before. In this paper we have shown the relationship between CSR and globalization. We pointed out that the relationship between business failure/ scandals increased after the globalization, and social responsible behavior. In this paper we have also discussed a case study "Limitations of CSR"

Index Terms: CSR, principles of CSR, Crisis, Globalization, Limitations and Governance
\end{abstract}

\section{Introduction}

Corporate Social Responsibility (or CSR as we will call it throughout this paper) is a concept which has become dominant in business reporting. Every corporation has a policy concerning CSR and produces a report annually detailing its activity. And of course each of us claims to be able to recognize corporate activity which is socially responsible and activity which is not socially responsible. Measurement and Evaluation of performance while giving flexibility for an organization to consider its own socially and environmentally significant factors and plan accordingly without being compared favorably or unfavorable with organizations with different priorities.

Globalization affects the economy, business life, society and environment in different ways, and almost all corporations have been affected by these changes. We can see these changes mostly related with increasing competition and the rapid changing of the technology and information transfer. This issue makes corporations more profit oriented than a long term and sustainable company. We need some social norms, rules and principles in society and business life for socially responsible behavior. The development and implementation of strategy is of course important for every organization, and this has always been so. Increasingly however in the present CSR is being considered as a crucial part of that strategy with corresponding advantages to the organization. In this paper therefore we will consider aspects of this in the context of the objectives of the firm and its procedures for governance.

\subsection{Definitions of CSR}

The broadest definition of corporate social responsibility is concerned with what it should be the relationship between global corporations, governments of countries and individual citizens. More locally the definition is concerned with the relationship between a corporation and the local society in which it resides or operates. Another definition is concerned with the relationship between a corporation and its stakeholders. This social contract implies some form of altruistic behavior the converse of selfishness whereas self-interest connotes selfishness. Self interest is central to the Utilitarian perspective championed by such people as Bentham, Locke and J. S. Mill. The latter, for example, is generally considered to have advocated as morally right the pursuit of the greatest happiness for the greatest number although the Utilitarian philosophy is actually much more based on selfishness than this something to which we will return later. Similarly Adam Smith's free market economics is predicated on competing self-interest.

These influential ideas put interest of the individual above interest of the collective. The central tenet of social responsibility however is the social contract between all the stakeholders to society, which is an essential requirement of civil society. This is alternatively described as citizenship but for either term it is important to remember that the social responsibility needs to extend beyond present members of society. Social responsibility also requires a responsibility towards the future and towards future members of society. 
Subsumed within this is of course a responsibility towards the environment which we will also return to later because of implications for other members of society both now and in the future.

There is however no agreed definition of CSR so this raises the question as to what exactly can be considered to be corporate social responsibility. According to the EU Commission [(2002) 347 final: 5],

"...CSR is a concept whereby companies integrate social and environmental concerns in their business operations and in their interaction with their stakeholders on a voluntary basis. ”

\subsubsection{Corporations are part of society}

A growing number of writers however have recognized that the activities of an organization impact upon the external environment and have suggested that one of the roles of accounting should be to report upon the impact of an organization in this respect. Such a suggestion first arose in the 1970's and a concern with a wider view of company performance is taken by some writers who evince concern with the social performance of a business, as a member of society at large.

Indeed the desirability of considering the social performance of a business has not always however been accepted and has been the subject of extensive debate.

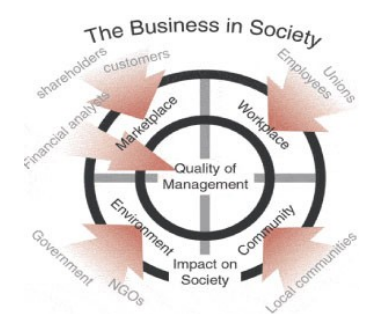

Thus Hetherington (1973: 37) states

"There is no reason to think that shareholders are willing to tolerate an amount of corporate non-profit activity which appreciably reduces either dividends or the market performance of the stock."

Conversely, writing at a similar time, Dahl (1972: 18) states

"....Every large corporation should be thought of as a social enterprise; that is an entity whose existence and decisions can be justified insofar as they serve public or social purposes "

\section{Similarly Carroll (1979), one of the early CSR theorists states that: \\ "Business encompasses the economic, legal, ethical and discretionary expectations that society has of organization at a given point in time”.}

\section{More recently this was echoed by Balabanis, Phillips and Lyall (1998), who declared that:}

"In the modern commercial area, companies and their managers are subjected to well publicized pressure to play an increasingly active role in [the welfare of] society."

\subsubsection{Profit is all that matters}

Some writers have taken the view that a corporation should not be concerned with social responsibility and you are certain to come across the statement from Milton Friedman, made in 1970:

"There is one and only one social responsibility of business to use its resources and engage in activities designed to increase its profits so long as it stays within the rules of the game, which is to say, engages in open and free competition without deception or fraud".

Equally some people are more cynical in their view of corporate activity. So Drucker (1984) had the opinion that:

"Business turns a social problem into economic opportunity and economic benefit, into productive capacity, into human competence, into well-paid jobs, and into wealth".

\subsubsection{CSR is conditional}

While Robertson and Nicholson (1996) thought that:

"A certain amount of rhetoric may be inevitable in the area of social responsibility. Managers may even believe that making statements about social responsibility insulates the firm from the necessity of taking socially responsible action."

\section{Moir (2001) is more ambivalent:}

"Whether or not business should undertake CSR, and the forms that responsibility should take, depends upon the economic perspective of the firm that is adopted". 
So we can see that CSR is a contested topic and it is by no means certain that everybody thinks that it is important or relevant to modern business.

\subsection{The effects of organizational activity}

It is apparent of course that any actions which an organization undertakes will have an effect not just upon itself but also upon the external environment within which that organization resides. In considering the effect of the organization upon its external environment it must be recognized that this environment includes both the business environment in which the firm is operating, the local societal environment in which the organization is located and the wider global environment. This effect of the organization can take many forms, such as:

- The utilization of natural resources as a part of its production processes.

- The effects of competition between itself and other organizations in the same market.

- The enrichment of a local community through the creation of employment opportunities.

- Transformation of the landscape due to raw material extraction or waste product storage.

- The distribution of wealth created within the firm to the owners of that firm (via dividends) and the workers of that firm (through wages) and the effect of this upon the welfare of individuals.

- And more recently the greatest concern has been with climate change and the way in which the emission of greenhouse gases are exacerbating this.

\subsection{The principles of CSR}

Because of the uncertainty surrounding the nature of CSR activity it is difficult to define CSR and to be certain about any such activity. It is therefore imperative to be able to identify such activity and we take the view that there are three basic principles which together comprise all CSR activity.

- Sustainability.

- Accountability.

- Transparency.

\subsubsection{Sustainability}

This is concerned with the effect which action taken in the present has upon the options available in the future. If resources are utilized in the present then they are no longer available for use in the future, and this is of particular concern if the resources are finite in quantity. Thus raw materials of an extractive nature, such as coal, iron or oil, are finite in quantity and once used are not available for future use. At some point in the future therefore alternatives will be needed to fulfill the functions currently provided by these resources. This may be at some point in the relatively distant future but of more immediate concern is the fact that as resources become depleted then the cost of acquiring the remaining resources tends to increase, and hence the operational costs of organizations tend to increase.

Sustainability therefore implies that society must use no more of a resource than can be regenerated. This can be defined in terms of the carrying capacity of the ecosystem (Hawken 1993) and described with input output models of resource consumption. Thus the paper industry for example has a policy of replanting trees to replace those harvested and this has the effect of retaining costs in the present rather than temporally externalizing them.

Viewing an organization as part of a wider social and economic system implies that these effects must be taken into account, not just for the measurement of costs and value created in the present but also for the future of the business itself. Measures of sustainability would consider the rate at which resources are consumed by the organization in relation to the rate at which resources can be regenerated. Unsustainable operations can be accommodated for either by developing sustainable operations or by planning for a future lacking in resources currently required. In practice organizations mostly tend to aim towards less sustainability by increasing efficiency in the way in which resources are utilized.

\subsubsection{Accountability}

This is concerned with an organization recognizing that its actions affect the external environment, and therefore assuming responsibility for the effects of its actions. This concept therefore implies a quantification of the effects of actions taken, both internal to the organization and externally. More specifically the concept implies a reporting of those quantifications to all parties affected by those actions. This implies a reporting to external stakeholders of the effects of actions taken by the organization and how they are affecting those stakeholders. 
This concept therefore implies recognition that the organization is part of a wider societal network and has responsibilities to that entire network rather than just to the owners of the organization. Alongside this acceptance of responsibility therefore must be a recognition that those external stakeholders have the power to affect the way in which those actions of the organization are taken and a role in deciding whether or not such actions can be justified, and if so at what cost to the organization and to other stakeholders.

Accountability therefore necessitates the development of appropriate measures of environmental performance and the reporting of the actions of the firm. This necessitates costs on the part of the organization in developing, recording and reporting such performance and to be of value the benefits must exceed the costs. Benefits must be determined by the usefulness of the measures selected to the decision-making process and by the way in which they facilitate resource allocation, both within the organization and between it and other stakeholders. Such reporting needs to be based upon the following characteristics:

- Understandability to all parties concerned;

- Relevance to the users of the information provided;

- Reliability in terms of accuracy of measurement, representation of impact and freedom from bias;

- Comparability, which implies consistency, both over time and between different organizations.

Inevitably however such reporting will involve qualitative facts and judgments as well as quantifications. This quality will inhibit comparability over time and will tend to mean that such impacts are assessed differently by different users of the information, reflecting their individual values and priorities. A lack of precise understanding of effects, coupled with the necessarily judgmental nature of relative impacts, means that few standard measures exist. This in itself restricts the inter organization comparison of such information. Although this limitation is problematic for the development of environmental accounting it is in fact useful to the managers of organizations as this limitation of comparability alleviates the need to demonstrate good performance as anything other than a semiotic.

\subsubsection{Transparency}

Transparency, as a principle, means that the external impact of the actions of the organization can be ascertained from that organization's reporting and pertinent facts are not disguised within that reporting. Thus all the effects of the actions of the organization, including external impacts, should be apparent to all from using the information provided by the organization's reporting mechanisms. Transparency is of particular importance to external users of such information as these users lack the background details and knowledge available to internal users of such information. Transparency therefore can be seen to follow from the other two principles and equally can be seen to be a part of the process of recognition of responsibility on the part of the organization for the external effects of its actions and equally part of the process of transferring power to external stakeholders.

\section{The prominence of CSR}

It is quite noticeable how much more prominent corporate social responsibility (CSR) has become not just in the academic world and in the business world but also is everyday life. We can highlight a lot of factors which have led to this interest such things as:

- Poor business behavior towards customers

- Treating employees unfairly

- Ignoring the environment and the consequences of organizational action.

Since then other things have also featured prominently in popular consciousness. One of these which has become more pronounced is the issue of climate change and this has affected concern about CSR through a concern with the emission of greenhouse gases and particularly carbon dioxide. Nowadays it is quite common for people to know and discuss the size of their carbon footprint whereas even three years ago people in general did not even know what a carbon footprint was.

Another thing which has become prominent is a concern with the supply chain of a business; in other words with what is happening in other companies which that company does business with their suppliers and the suppliers of their suppliers. In particular people are concerned with the exploitation of people in developing countries, especially the question of child labor but also such things as sweat shops.

So no longer is it acceptable for a company to say that the conditions under which their suppliers operate is outside of their control and so they are not responsible. Customers have said that this is not acceptable and have called companies to account. And there have recently been a number of high profile retail companies which have held their hands up to say mea culpa2 and taken very public steps to change this. 
Interestingly the popularity of companies increases after they have admitted problems and taken steps to correct these problems. In doing this they are thereby showing both that honesty is the best practice and also that customers are reasonable. The evidence suggests that individual customers are understanding and that they do not expect perfection but do expect honesty and transparency. Moreover they also expect companies to make efforts to change their behavior and to try to solve their CSR problems.

\subsection{Changing emphasis in companies}

Companies themselves have also changed. No longer are they concerned with green washing the pretence of socially responsible behavior through artful reporting. Now companies are taking CSR much more seriously not just because they understand that it is a key to business success and can give them a strategic advantage, but also because people in those organizations care about social responsibility.

So it would be reasonable to claim that the growing importance of CSR is being driven by individuals who care but those individual are not just customers, they are also employees, managers, owners and investors of a company. So companies are partly reacting to external pressures and partly leading the development of responsible behavior and reporting. So accountability one of the central principles of CSR is much more recognized and is being responded to by increasing transparency another of the principles of CSR.

\subsubsection{Recognizing CSR}

Most people initially think that they know what CSR is and how to behave responsibly and everyone claims to be able to recognize socially responsible or irresponsible behavior without necessarily being able to define it. So there is general agreement that CSR is about a company's concern for such things as community involvement, socially responsible products and processes, concern for the environment and socially responsible employee relations (Ortiz-Martinez \& Crowther 2006).

Issues of socially responsible behavior are not of course new and examples can be found from throughout the world and at least from the earliest days of the Industrial Revolution and the concomitant founding of large business entities (Crowther 2002) and the divorce between ownership and management or the divorcing of risk from rewards (Crowther 2004). According to the European Commission CSR is about undertaking voluntary activity which demonstrates a concern for stakeholders.

But it is here that a firm runs into problems how to balance up the conflicting needs and expectations of various stakeholder groups while still being concerned with shareholders; how to practice sustainability; how to report this activity to those interested; how to decide if one activity more socially responsible that another. The situation is complex and conflicting. In this paper therefore the contributors are concerned with different aspects of CSR, both with theorizing and with implementing CSR in practice.

\subsection{Crisis}

The recent financial scandals and industrial bankruptcies have had consequences on the business perspective of managers and stockholders. This situation has strengthened the tendency to believe in a necessary change of business, which entails focusing on a wider concept of entrepreneurial profit with a long-term view and giving the proper importance to stakeholders, people or groups of people that affect or are affected by a firm's activity.

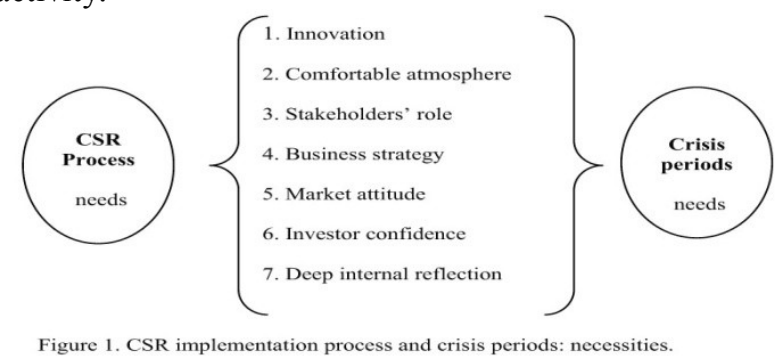

Therefore, the key question is whether there is any relation between CSR and economic magnitudes linked to prosperity, and if so, what is this relation like? There is ample literature dealing with these questions, but the result is inconsistent. Links between CSR and cost, profit, long-range survival, etc. are not clear.

The following table (Table 1) shows a summary of the state of the art, reflecting the confusing scenery around CSR and its relationship with financial performance, shareholder's value and investor's perspective, among other economic and financial parameters. 
Author

Conclusion

\begin{tabular}{|c|c|}
\hline $\begin{array}{l}\text { Ingram and } \\
\text { Frazier, } 1983\end{array}$ & $\begin{array}{l}\text { Environmental performance has a neg } \\
\text { effect on financial statements }\end{array}$ \\
\hline reeman, 1984 & $\begin{array}{l}\text { CSR minimizes transaction costs and potential } \\
\text { conflicts with stakeholders }\end{array}$ \\
\hline $\begin{array}{l}\text { oloman and } \\
\text { ansen, } 1985\end{array}$ & $\begin{array}{l}\text { SR costs are clearly covered with benefits in } \\
\text { mployee morale and productivity }\end{array}$ \\
\hline $\begin{array}{l}\text { eedman and } \\
\text { ggi, } 1982\end{array}$ & CSR and shareholder's value don't coincide \\
\hline $\begin{array}{l}\text { ava and Krausz, } \\
996\end{array}$ & $\begin{array}{l}\text { CSR and financial performance are positively } \\
\text { linked }\end{array}$ \\
\hline $\begin{array}{l}\text { reston and } \\
\text { 'Bannon, } 1997\end{array}$ & $\begin{array}{l}\text { CSR and the magnitude of financial evolution } \\
\text { coincide }\end{array}$ \\
\hline $\begin{array}{l}\text { Waddock and } \\
\text { Graves, } 1997 .\end{array}$ & $\begin{array}{l}\text { Social and economic performance have } \\
\text { opposite consequences on financial statements }\end{array}$ \\
\hline $\begin{array}{l}\text { tanwick and } \\
\text { tanwick, } 1998\end{array}$ & $\begin{array}{l}\text { Importance of stakeholders' recognition for a } \\
\text { positive evolution of financial magnitudes }\end{array}$ \\
\hline Verschoor, 1998 & $\begin{array}{l}\text { Positive relationship between corporate } \\
\text { performance and stakeholder relationships }\end{array}$ \\
\hline Jensen, 2001 & $\begin{array}{l}\text { Social constraints and responsible } \\
\text { behaviour can work against value } \\
\text { maximization. }\end{array}$ \\
\hline Ruf et al., 2001 & $\begin{array}{l}\text { CSR and sales increase are observed in } \\
\text { several companies, with temporal continuity }\end{array}$ \\
\hline Bauer et al., 2002 & $\begin{array}{l}\text { Comparison of ethical and traditional } \\
\text { investment finds mixed results, with a light } \\
\text { positive trend towards ethical funds }\end{array}$ \\
\hline $\begin{array}{l}\text { Orlitzky et al., } \\
2003\end{array}$ & $\begin{array}{l}\text { The results of their meta-analysis confirm a } \\
\text { positive relation between social responsibility } \\
\text { and financial performance }\end{array}$ \\
\hline $\begin{array}{l}\text { 3arnea a } \\
005\end{array}$ & $\begin{array}{l}\text { CSR investment is negatively related to } \\
\text { insiders' ownership }\end{array}$ \\
\hline
\end{tabular}

\subsection{The Social Contract}

In 1762 Jean-Jacques Rousseau produced his book on the Social Contract which was designed to explain and therefore legitimate the relationship between and individual and society and its government. In it he argued that individual's voluntary gave up certain rights in order for the government of the state to be able to manage for the greater good of all citizens. This is of course a sharp contrast to the angry rhetoric of Tom Paine, shown above. Nevertheless the idea of the Social Contract has been generally accepted.

This can be depicted thus:

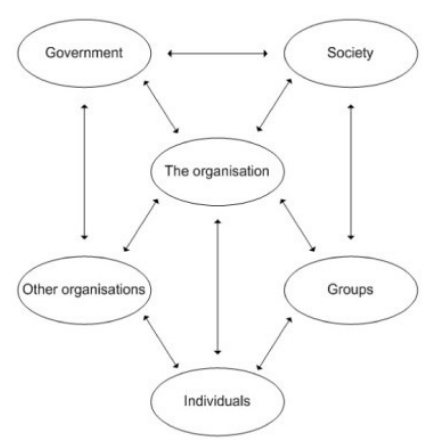

Fig 2.1 The Social Contract

More recently the Social Contract has gained a new prominence as it has been used to explain the relationship between a company and society. In this view the company (or other organization) has obligations towards other parts of society in return for its place in society.

This in turn led to the development of Stakeholder Theory.

\section{The Tasks of a Manager}

We have seen how the role of a manager of a business will vary greatly according to his area of responsibility. We have also seen how the manager needs to help the organization meet its objectives and that these can vary significantly from one organization to another. The roles of different managers are therefore very 
different and the tasks which they undertake to perform their roles are also very different. Nevertheless we can classify these different tasks into one of several types according to their nature. These tasks can be classified as follows:

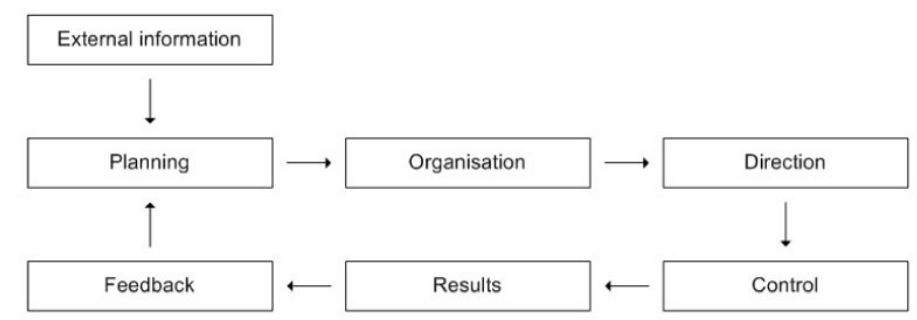

Fig 3.1 The tasks of management

\subsection{Planning}

A manager needs to plan for the future in order to decide how best to meet the objectives of the organization. He needs to decide what can be achieved and what inputs are needed to help him meet his plan. Planning therefore needs to be not just qualitative but also quantitative in order to evaluate the plan and determine inputs and outputs to the plan. All business processes can be considered as taking a set of inputs and performing operations in order to add value and transform them into outputs. The function of any business can therefore considered to be adding value through the transformations made during its processing. This can be illustrated as follows:

\begin{tabular}{cc}
\hline Inputs & $\longrightarrow \begin{array}{c}\text { Added value through } \\
\text { operations }\end{array}$ \\
Fig 3.2 The transformational process
\end{tabular}

Planning needs to consider alternatives, not just in terms of alternative targets to set but also in terms of alternative methods of achieving these targets. Planning cannot be done in isolation but needs to take into account what effect the planning has upon the plans of other managers within the organization. This is especially true when the inputs of this plan come from the outputs of the plan of another manager or when these outputs affect the planning of another manager.

Thus a sales manager cannot plan how much to sell without taking into account the plan of the production manager concerning how much will be produced, and the production manager cannot make his plans for production without taking into account the planning of the sales manager regarding how much can be sold. The planning tasks of the manager therefore are important but cannot be made in isolation.

\subsection{Control}

Control is concerned with making sure that things happen in accordance with the plan. It therefore involves monitoring the plan, and progress being made in accordance with the plan. It also involves taking action when things are not going in accordance with the plan in order to attempt to change things so that the plan can be achieved. Control is therefore an ongoing activity for a manager and involves comparing actual performance with targets, providing feedback on actual performance and taking action to change performance when it diverges from the plan. Although the manager may be able to achieve this by physical observation and communication with people, it is likely that this will not be sufficient. He will probably need to rely to a large extent upon reports in order to exercise control. The reports which management accounting provide are therefore crucial in assisting a manager to exercise control.

\subsection{Decision making}

One of the key aspects of a manager's job is concerned with making decisions. There is always more than one course of action which a manager can take in any particular situation (even if one of the courses is to do nothing!) and so he needs to decide between the alternatives in order to make the decision which is most beneficial. In order to make a decision the manager needs to identify the possible alternative courses of action open to him, to gather data about those courses of action and to evaluate the consequences of each particular alternative. The stages in the decision making process are shown in the diagram below, which illustrates that the decision making process is not complete when an alternative has been selected and implemented but that the outcomes of the decision need to be followed through into the control process.

In order to make a decision a manager needs information. Management accounting is one tool which exists to help the manager by providing information about the consequences of the alternatives open to him. 


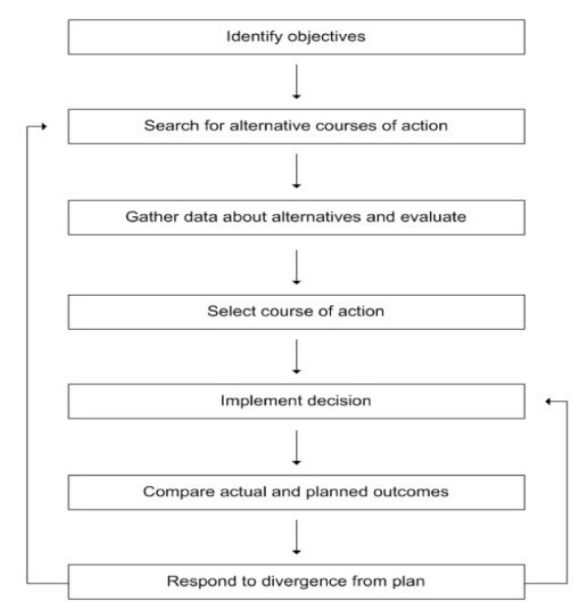

Fig 3.3The Decision Making Process

\subsection{Performance evaluation}

While the performance of organizations is evaluated by such measures as return on capital employed, the organization in turn needs to evaluate the performance of its units and the managers running these units. The managers in turn need to evaluate the actual performance of their tasks against that which has been planned. In order to evaluate performance there needs to be acceptable measures of performance. Measurement needs to be relative to be meaningful to compare performance with plans and with past performance. Performance measures also need to be quantitative in order to enable comparisons to be made and financial information provides important data for the measurement of performance. Unless performance can be evaluated managers have no basis upon which to exercise control, to make decisions and to plan for the future.

\subsection{Communication}

Information available to help managers in their tasks needs to be communicated to them, and managers in turn need to communicate their plans and decisions to others. Communication involves both the sender of information and its recipient and for the information to be of value it needs to be understood by the recipient as intended by the sender. Any interference which prevents the message being received by the recipient is known as noise and the diagram below shows that two types of noise prevent a message being received as transmitted. Technical noise is that such as occurs on a telephone or radio which is concerned with the technical means of communication. A more crucial type of noise however is semantic noise which occurs because a message is not transmitted in a clear and unambiguous manner and so is not correctly understood by the recipient. Quantitative information is less likely to be misunderstood than qualitative information and this is one of the importance features of accounting information. Management accounting therefore has an important part to play not just in enabling decisions to be made but also in the communication of this information.

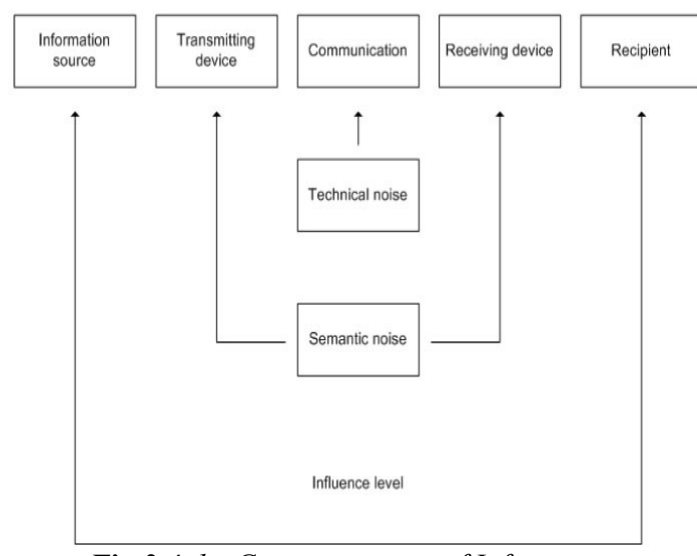

Fig 3.4 the Communication of Information 


\section{Corporate Governance Principles}

Since corporate governance can be highly influential for firm performance, firms must know what the corporate governance principles are and how it will improve strategy to apply these principles. In practice there are four principles of good corporate governance, which are:

- Transparency.

- Accountability.

- Responsibility.

- Fairness.

All these principles are related with the firm's corporate social responsibility. Corporate governance principles therefore are important for a firm but the real issue is concerned with what corporate governance actually is.

Management can be interpreted as managing a firm for the purpose of creating and maintaining value for shareholders. Corporate governance procedures determine every aspect of the role for management of the firm and try to keep in balance and to develop control mechanisms in order to increase both shareholder value and the satisfaction of other stakeholders. In other words corporate governance is concerned with creating a balance between the economic and social goals of a company including such aspects as the efficient use of resources, accountability in the use of its power, and the behavior of the corporation in its social environment.

The definition and measurement of good corporate governance is still subject to debate. However, good corporate governance will address all these main points:

- Creating sustainable value.

- Ways of achieving the firm's goals.

- Increasing shareholders' satisfaction.

- Efficient and effective management.

- Increasing credibility.

- Ensuring efficient risk management.

- Providing an early warning system against all risk.

- Ensuring a responsive and accountable corporation.

- Describing the role of a firm's units.

- Developing control and internal auditing.

- Keeping a balance between economic and social benefit.

- Ensuring efficient use of resources.

- Controlling performance.

- Distributing responsibility fairly.

- Producing all necessary information for stakeholders.

- Keeping the board independent from management.

- Facilitating sustainable performance.

As can be seen, all of these issues have many ramifications and ensuring their compliance must be thought of as a long term procedure. However firms naturally expect some tangible benefit from good governance. So good governance offers some long term benefit for firms, such as:

- Increasing the firm's market value.

- Increasing the firm's rating.

- Increasing competitive power.

- Attracting new investors, shareholders and more equity.

- More or higher credibility.

- Enhancing flexible borrowing condition/facilities from financial institutions.

- Decreasing credit interest rate and cost of capital.

- New investment opportunities.

- Attracting better personnel / employees.

- Reaching new markets.

Although corporate governance is primarily considered to be concerned with how a firm conducts itself in relationship to its investors, increasingly it is being extended to a consideration of how it conducts itself in 
relation to all of its stakeholders. This is a part of the current concern for greater accountability. Thus governance is increasingly being considered to be related to CSR and the concerns of the two are merging (Aras \& Crowther 2009).

\section{Globalization}

Globalization can be defined as the free movement of goods, services and capital. This definition does not cover all the aspects of globalization or global changing. Globalization also should be a process which integrates world economies, culture, technology and governance. This is because globalization also involves the transfer of information, skilled employee mobility, the exchange of technology, financial funds flow and geographic arbitrage between developed countries and developing countries. Moreover globalization has religious, environmental and social dimensions.

In order to encompass this broad impact area globalization covers all dimensions of the world economy, environment and society. Moreover it is apparent all over the world and the world is changing dramatically. Every government has a responsibility to protect all of their economy and domestic market from this rapid changing. The question is how a company will adapt to this changing. First of all companies have to know different effects of globalization. Globalization has some opportunities and threats. A company might have learned how to protect itself from some negative effects and how to get opportunities from this situation.

\subsection{Factors affecting globalization theory.}

Globalization affects the economy, business life, society and environment in different ways:

- Increasing competition.

- Technological development.

- Knowledge/Information transfer.

- Portfolio investment (fund transfer between developed countries and emerging markets).

- Regulation/deregulation, International standards.

- Market integration.

- Intellectual capital mobility.

- Financial crisis-contagion effect-global crisis.

\subsubsection{Competition}

Globalization leads to increased competition. (Increased competition is a consequence of globalization) This competition can be related to product and service cost and price, target market, technological adaptation, quick response and quick production by companies etc. When a company produces with less cost and sells cheaper, it will be able to increase its market share. Customers have too much choice in the market and they want to acquire goods and services quickly and in a more efficient way. And also they are expecting high quality and a cheap price which they are willing to pay. All these expectations need a response from the company, otherwise sales of company will decrease and they will lose profit and market share. A company must be always ready for price, product and service and customer preferences because all of these are global market requirements.

\subsubsection{Exchange of Technology}

One of the most striking manifestations of globalization is the use of new technologies by entrepreneurial and internationally oriented firms to exploit new business opportunities. Internet and ecommerce procedures hold particular potential for SMEs seeking to broaden their involvement into new international markets (Wrighta \& Etemad, 2001). Technology is also one of the main tools of competition and the quality of goods and services. On the other hand it necessitates quite a lot of cost for the company. The company has to use the latest technology for increasing their sales and product quality. Globalization has increased the speed of technology transfer and technological improvement. Customer expectations are directing markets. Mostly companies in capital intensive markets are at risk and that is why they need quick/rapid adapting concerning the customer/market expectations. These companies have to have efficient technology management and efficient R\&D management.

\subsubsection{Knowledge/Information transfer}

Information is a most expensive and valuable production factor in the current environment (presently/currently/at the current time) Information can be easily transferred and exchanged from one country to another. If a company has a chance to use knowledge and information then it means that it can adapt to this global changing. This issue is similar with the technology transfer issue in global markets. The rapid changing of the market requires also quick transfer of knowledge and efficient using of that knowledge and information. 


\subsubsection{Portfolio investment (Financial fund flows)}

Globalization encourages increased international portfolio investment. Additionally, financial markets have become increasingly open to international capital flows. For this reason, portfolio investment is one of the major problems of developing economies. It is almost the only way to increase liquidity of the markets and economies for emerging countries through attracting foreign funds. Significantly, this short term investment can dramatically impact on the financial markets. When the emerging economies have some problem in their country or investors make enough profit from their investment then these investors might leave the market. This would mean that market liquidity decreased and financial markets indicators plummet immediately.

\subsubsection{Regulation/deregulation and international standards}

Globalization needs more regulation of the markets and economy. There are many new and complicated financial instruments and methods in the market and such instruments easily transfer and trade in other countries because of the globalization effect. Every new system, instrument or tool requires new rules and regulations to determine its impact area. These regulations are also necessary to protect countries against global risks and crises. When the crisis comes out of one country then it influences other countries with trade channels and fund transfers, which we call the contagion effect. On the other hand, during globalization the shares of big companies are trading in the international stock markets and these companies have shareholders and stakeholders in many different countries. International rules and regulations also offers protection to small investors against the big scandals and other problems in companies. International standards also regulate markets and economies by means of international principles and rules such as International accounting standards, international auditing standards. It aims to make corporate reporting standardized and comparable So that is why the globalised world has more rules and more regulations and international standards than before.

\subsubsection{Market integration}

In fact globalization leads to the conversion of many markets and economies into one market and economy. The aim of international standards and regulations is also to deregulate all these markets. The economy needs financial structures capable of handling the higher risk in the new economy. For this reason financial markets must be broad, deep, and liquid and at present only the U.S. financial markets are large enough to provide this financial structure in the world market. Global stock market projection and Pan-European stock market projection are part of this changing. There are many similar examples in the current situation for market integration which are also the result of increasing competition in the economy. Integration examples are prominent in company mergers and acquisitions as well.

\subsubsection{Qualitative Intellectual capital mobility}

Another effect of globalization is human capital mobility through knowledge and information transfers. One of the reasons is that international/multinational companies have subsidiaries, partners and agencies in different countries. They need skilled and experienced international employees and rotation from country to country to provide appropriate international business practice. This changing also requires more skilled, well educated and movable employees who can adapt quickly to different market conditions.

\subsubsection{Financial crisis-contagion effect-global crisis}

Financial crises are mostly determined through globalization and as a result of the globalization impact. In fact, this is quite a true explanation. The financial world has witnessed a number of crises cases. Generally financial crises come out from international funds/capital flows (portfolio investments), lack of proper regulations and standards, complex financial instruments, rapid development of financial markets, asymmetric information and information transfers. One country crisis can turn into a global crisis with systemic risk effect. Systemic risk refers to a spreading financial crisis from one country to another country. In some cases, crises spread even between countries which do not appear to have any common economic fundamentals/problems. Previous global crises have also showed that one of the reasons for the crisis is unregulated markets.

\subsection{How Globalization Affects CSR}

The question might be how globalization affects CSR. But the answer to this question is not only related to the last quarter of the 20th century but also related to previous centuries. John Maynard Keynes calculated that the standard of living had increased 100 percent over four thousand years. Adam Smith had an important (seminal) idea about the wealth of communities and in 1776 he described conditions which would lead to increasing income and prosperity. Similarly there is much evidence from economic history to demonstrate the benefit of moral behavior; for example, Robert Owen in New Lanark, and Jedediah Strutt in Derbyshire both in the UK showed the economic benefits of caring for stakeholders. More recently Friedman has paid attention to the moral impact of the economic growth and development of society. 
Moreover, they are responsible to the shareholders for making more profit to keep their interest long term in the company. Therefore they are taking risk for their benefit/profit. This risk is not opposed to the social or moral/ethical principles which they have to apply in the company. There are many reasons for ethical and socially responsible behavior of the company. However, there are many cases of misbehavior and some illegal operations of some companies. Increasing competition makes business more difficult than before in the globalised world. The good news and our expectations are that competition will not have any longer bad influence on company behavior. According to international norms (practice) and expectations, companies have to take into account social, ethical and environmental issues more than during the last two decades. One of the reasons is more competition not always more profit; another reason is consumer expectation is not only related to the cost of products but also related to quality, proper production process and environmental sensitivity.

Moreover shareholders are more interested in long term benefit and profit from the company. The key word of this concept is long term which represents also a sustainable company. Shareholders want to get long term benefit with a sustainable company instead of only short term profit. This is not only related to the company profit but also related to the social and environmental performance of the company. Thus, managers have to make strategic plans for the company concerning all stakeholder expectations which are sustainable and provide long term benefit for the companies with their investments.

Globalization has had a very sharp effect on company behavior and still we can see many problems particularly in developing countries. This is one of the realities of the globalization process. However we are hoping to see some different approaches and improvements to this process with some of them naturally related to some international principles, rules and norms. But most of them are related to the end of this flawed system and the problems of capitalization.

\subsection{Globalization, Corporate Failures and CSR}

Corporate failures bring out some governance and CSR issues and have increased attention to the role of business ethics. Managers and CEO's of these companies must be considered responsible for all of these failures and these are cases of "corporate irresponsibility". Many people have the opinion that if corporations were to behave responsibly, most probably corporate scandals would stop. CSR protects firms against some long term loss. When corporations have social responsibilities, they calculate their risk and the cost of failure. Firstly, a company has to have responsibility to share holders and also all stakeholders which means that it has responsibility to all society. Corporate failures have an important impact on all society also.

One of the reasons for this result is increasing competition between the company and the market. Managers tend to become much more ambitious than before in their behavior and status in the globalised world. Thus we have to focus on corporate and managerial behavior. The question is how to behave as a socially responsible manager and how to solve this vital problem in business life and in society. In the business world there are always some rules, principles and norms as well as regulations and some legal requirements.

However, to be socially responsible one must be more than simply law abiding who has to be capable of acting and being held accountable for decisions and actions. The problem is the implication for all of these directions for company and managerial behavior. On the other hand, one perspective is that a corporation is a "legal person" and has the rights and duties that go with that status including social responsibility. In the case of Enron, managers were aware of all regulations, even though they have known all irresponsible and unethical problems in the company management; they did not change their approach and behavior.

The conclusion is that it is not always possible to control behavior and corporate activity with regulations, rules and norms. So another question arises in this situation, that if people do not know their responsibility and socially responsible things to do and if they do not behave socially responsibly then, who will control this problem in business life and in the market. The concern is that the social responsibility implication of the company cannot be controlled through legal means. This is the only social contract between mangers and society and stakeholders of the company and for responsible and accountable behavior.

\subsection{Is Globalization an opportunity or threat for CSR?}

We have no certain answer for this question which is depends on from where are you are looking. It is clear that the globalization has different effects on the social responsibility of the company and the behavior of managers. Some of these are supporting companies/managers for motivating towards socially responsible behavior, while others of them are destroying fair business and all principles, norms and regulations which are the result of increasing competition. Globalization has been created bigger companies in terms of turnover, market capitalization, and amount of assets. This causes imperfect competition with other small and medium size companies which is a major threat for them.

But it might also provide to companies great opportunities for reaching people and customers, and for collaboration with other companies from all over the world. In fact we have to accept that globalization is an inevitable phenomenon for which we have no alternative yet. Well regulated and controlled markets are not a 
big problem and threat, but lack of regulation and norms is the main problem in a developing country which globalization has a big influence in these economies. Moreover CSR implementation is the one of the most important issues for globalised economies and markets. CSR requires some rules for the determination of the relationship between the corporation and society, which is still a complicated process. The implication is that CSR is not merely a simple process but also needs a long term strategic approach by companies which need to learn socially responsible behavior and their decision makers must enforce these principles in the company.

The duty of corporations is serving their shareholder through providing proper products and services. The purchasing decision of the customer is not only related with price and quality but also based on a consideration of the social behavior of the company. Socially responsible investment and behavior gives some opportunities to the company which is more visible than others and show more concern for stakeholders also. In particular, the development of information technology is helpful for the company for trading in any place in the world to any customer. Customers want the corporation to behave properly to its suppliers, and their suppliers to treat their laborers fairly even in far distant countries. When the company behaves unethically then people will know this problem all over the word and its effect on company sales and stakeholder interests for the company.

As a In summary, a firm has an investment in reputation, including its reputation for being socially responsible. An increase in perceived social responsibility may improve the image of the firm's management and permit it to exchange costly explicit claims for less costly implicit charges. In contrast, a decline in the level of stakeholders' view of a firm's social responsibility may reduce its reputation and result in an increase in costly explicit claims (Mcguire \& Sundgren \&Schneeweis,1988), We can also confidently say about CSR's impact at the present time is that it benefits some people and some companies in some situations. Consequently thought is being given to the implications of CSR for the developing world (Blowfield M, J. G. Frynas, 2005).

\subsection{CASE STUDY:}

(a)Richmond. The nation's top distributor of clove cigarettes is offering fans a new way to get their fix after the spice-flavored cigarettes are banned later this year cigars. Cloves: Also known as kreteks (pronounced "creeechs"), the cigarettes contain tobacco blended with cloves. They originated in the 1880s in Indonesia and are a staple of the Indonesian smoking culture so much so that companies like Philip Morris International Inc. have created their own blends of clove cigarette bearing the famous Marlboro name in Indonesia and India. The company also has a controlling interest in Sampoerna, another Indonesian maker of clove cigarettes. Indonesia exports more than $\$ 500$ million worth of the product per year, with about a fifth of the shipments coming to the U.S. The industry employs about 11 million Indonesian workers. The new filtered cigars close to the size of a cigarette and flavored with clove, vanilla and cherry allow Moorpark-based Kretek International Inc., which imports Djarum-brand tobacco products from Indonesia, to avoid new federal laws banning flavored cigarettes other than menthol.

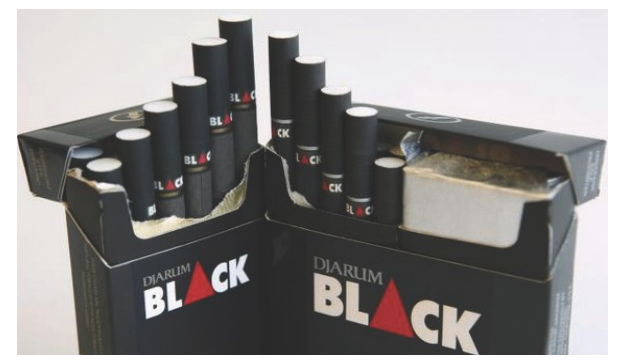

Fig. 6 Djarum Black Clove Cigars

The ban on flavored cigarettes, which critics say appeal to teenagers, goes into effect at the end of September 2009. It does not include cigars. The ban is one of the first visible effects of a new law signed by President Barrack Obama in June that gives the Food and Drug Administration wide-ranging authority to regulate tobacco, though it cannot ban nicotine or tobacco outright.

(b)Samsung. It has been criticized in 2008 for Lack of Recycling Programs. The Electronics Take Back Coalition has launched a marketing campaign attacking Samsung for not taking environmental responsibility to recycle old electronics that may contain toxic metals. The campaign aims to make consumers aware of toxic metals used to manufacture TVs and other electronic devices before 2005, and to point consumers to the fact that Samsung has been spending millions on ad campaigns during the Olympic instead of funding a take-back program for potentially toxic components in older TVs.

The "Take Back My TV" campaign is on the coalition's site, Metal Mania; a spoof of Samsung's site Medal Mania. The Electronics Take Back Coalition has launched a marketing campaign attacking Samsung for 
what it considers a weak stance on environmental protection and electronics recycling. The "Take Back My TV" campaign aims to make consumers aware of toxic metals used to manufacture TVs and other electronic devices prior to 2005 (Figure 7).

"Medal Mania" launched on July 24th 2008 and it lasted until the closing ceremonies of the Beijing 2008 Olympic Games on August 24th. Samsung Mobile has included a few FM sites (roadblocks on Bleacher Report, sponsorship of Water cooler's Olympics Face book app, etc.) in their "Medal Mania" treasure hunt campaign, where registered players get email hints telling them where to find Samsung Easter-egg ads at various sites across the web. Players rack up "medals" for each click and improve their odds at winning $\$ 100,000$ (the grand prize) or Samsung phones, flat panel TVs and other home entertainment goodies.

Both sites allow consumers to hunt for gold. But on the coalition's site, consumers find toxic metals mercury and cadmium instead of the gold and prizes found on Samsung's site. In response Samsung said in a statement that it is piloting a TV take-back and recycling programs in 14 U.S. states, and that it also "has numerous take-back and recycle initiatives throughout the company."

(c)Wal-Mart. It has been criticized specifically for its extensive foreign product sourcing, low rates of employee health insurance enrollment, resistance to union representation and sexism. Conversely, others point out that Wal-Mart's rapid growth and logistical efficiency has enabled it to bring lower prices to consumers and more low paying jobs and new small businesses to the communities in which it operates.

Wal-Mart's product selection has been criticized by some groups in the past, primarily as viewed as a promotion of a particular ideology or as a response to its original rural, religious target market. In 2003, WalMart removed certain men's magazines from its shelves, such as Maxim, FHM, and Stuff, because the retail chain has received complaints from customers about their racy content. Later that year, it decided to partly obscure the covers of Cosmopolitan, Marie Claire and Redbook on store shelves due to "customer concerns", and refused to stock an issue of Sports Illustrated swimsuit special because it took exception to one photograph. In 2004, Wal-Mart carried the anti-Semitic forgery The Protocols of the Elders of Zion in its online catalogue and Wal-Mart's online product description suggested the text might be genuine. The Jewish civil rights organization the Anti-Defamation League wrote to the President of Wal-Mart in September 2004 noting the text, "has been the major weapon in the arsenals of anti-Semites around the world," and called on Wal-Mart to, "unequivocally state the nature of the book and to disassociate itself from any endorsement of it.". Wal-Mart stopped selling the book shortly thereafter.

Wal-Mart has been accused of allowing illegal immigrants to work in its stores. On October $23^{\text {rd }}, 2003$, Federal officials raided Wal-Mart stores across the United States, arresting about 250 illegal immigrants working on cleaning crews at 61 stores in 21 states. It was about undocumented workers from Mexico, Eastern Europe and other countries who were employed by several contractors used by the world's largest retailer. Many of those arrested in the crackdown, which officials called "Operation Rollback," were coming off night cleaning shifts at various Wal-Mart stores. Following the arrests, a grand jury convened to consider charging Wal-Mart executives with labor racketeering crimes for knowingly allowing illegal immigrants to work at their stores. In November

2005, 125 alleged undocumented immigrants were arrested while working on construction of a new Wal-Mart distribution center in eastern Pennsylvania. The workers were employees of Wal-Mart's construction subcontractor.

In 2005, well-publicized lawsuit put the company's compensation policies in the public spotlight. A documentary film The High Cost of Low Prices examined the social repercussions of the retailer's presence in American communities.

Also, Wal-Mart has been accused of destroying of small communities by putting small retailers out of business. However, Wal-Mart is estimated to have lost about 8 percent of its market share because of reactions to such practices from consumers. Maclean's magazine published findings by Jantzi Research, one of Canada's leading CSR research firms, that gave the retail giant only a " $\mathrm{C}+$ " on its social responsibility report card. The Gap, on the other hand, has taken the opposite approach, earning an "A" in the Maclean's report. This retailer has been applauded for its corporate citizenship, through such actions as supporting African women and children with HIV/AIDS, monitoring the labor standards in its suppliers' factories, and adopting progressive social and environmental initiatives including the donation of damaged clothing to hospitals.

Wal-Mart's CSR picture, however, may not be all that bleak. Lee Scott, Wal-Mart's CEO, is committed to ambitious environmental goals, including zero waste, $100 \%$ renewable energy, and environmentally friendly products. In 2007, the company released its first Sustainability Report and soon expects to launch a Supply Chain Sustainability Scorecard. 


\section{Limitations Of Csr}

Figure 6.1 illustrates how the stakeholder dialogue can be interpreted as a modeling process in three phases. Each phase has a "filter" that makes the stakeholder dialogue more operable, but also limits the benefits that the company can expect to derive from the initiatives. Based on CSR literature and two case examples from the biotech based Danish company Novozymes, the article focuses on how these filters affect the operation of the stakeholder dialogue. The case analysis is based on an interpretation of interviews made at Novozymes and on secondary information about the two examples.

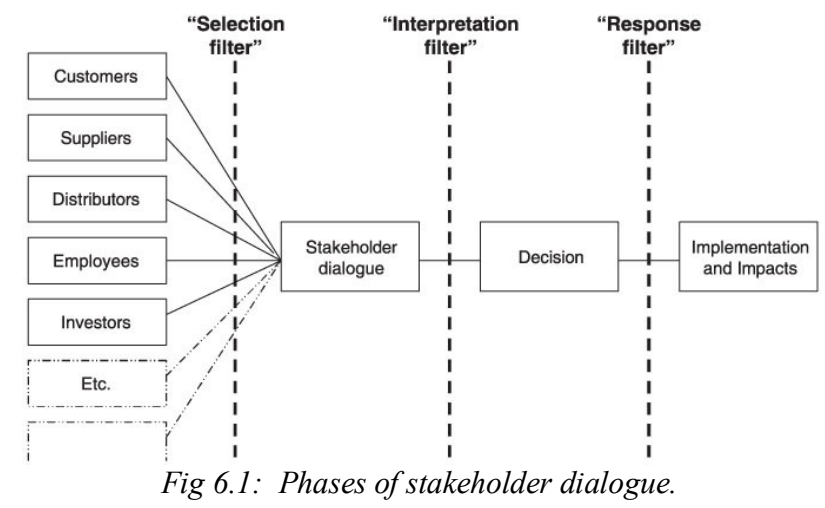

- The selection filter. Needless to say, stakeholder dialogue requires participants. The selection filter is about the access to the dialogue "arena." Does a wide range of stakeholders participate in the dialogue or is it limited to a few privileged groups with whom the company already communicates? Companies are unlikely to have the capacity to include all stakeholders in the dialogue and therefore a selection must be made a selection that will have consequences for the process and outcome of the dialogue. For instance, the composition of the stakeholders can have an impact on whether the issues raised in the dialogue arena are important and central or peripheral and uncontroversial.

- The interpretation filter. The interpretation filter concerns the transformation of the multiple voices from the dialogue into a limited number of decisions. Stakeholder dialogue is a complicated process and it may not be possible to come up with solutions that satisfy all stakeholders. Moreover, a number of factors can make it difficult to reach results that capture the interests of the stakeholders in the dialogue. For instance, cliques and alliances may arise that are able to dominate the agenda, the voices of some stakeholders may be overheard or misunderstood, latent conflicts may be suppressed, and problems may remain unsolved. In other words, the interpretation filter means that intentionally or unintentionally the decisions ensuing from the dialogue may diverge from the interests of the stakeholders.

- The response filter. Finally, the response filter relates to the activities that take place when the decisions move out of the dialogue arena. Local interpretations, changing environmental conditions, conflicting interests, and organizational changes may influence the way the results of the dialogue are implemented. The response filter represents the divergence between the observable action and the intentions underlying the decisions ensuing from the stakeholder dialogue.

\section{Case Example: Novozymes (For Limitations Of Csr)}

Novozymes is a biotech-based Danish company in the enzymes market. Enzymes for the industrial sector (textiles, pharmaceuticals, forestry, baking, brewing, etc.) constitute the most important product category and account for $95 \%$ of Novozymes' sales (Novozymes.com). In 2004; Novozymes had revenue of approximately US $\$ 1,050$ million and a net profit of approximately US $\$ 140$ million. The company employs some 4,000 persons and has production facilities in Denmark, Sweden, Switzerland, the United States, Brazil, and China.

Novozymes became an independent company in 2000 after a demerger from Novo Nordisk. Although the company has only been independent for a mere five years, Novozymes already has been engaged in a number of CSR activities, and its performance has not gone unnoticed. Novozymes has been ranked number one in the Dow Jones Sustainability Indexes (DJSIs) (within its fields Biotechnology / Healthcare) for five years in a row, and for three years the company has been recognized by SustainableBusiness.com on their top 20 list of the world's most sustainable business stocks. Moreover, the company subscribes to and/or supports a number of international initiatives, conventions, declarations, and standards (e.g., the UN Global Compact, the International Chamber of Commerce's Charter for Sustainable Development, the UN Convention on Biological 
Diversity, and the UN Universal Declaration of Human Rights). Novozymes' achievements are documented in an integrated annual report that covers financial, social, and environmental performance. The annual report also includes information on Novozymes' use of global reporting initiative indicators, progress with regard to the Global Compact, and achievements of sustainability development targets. The form and content of the integrated annual report has been the subject of discussions with the users of the report, including employees, NGOs, media, and scientists.

In terms of stakeholder dialogue, it is explicitly stated in the company's values that Novozymes "shall seek an active dialogue with our stakeholders to help us develop and strengthen our business." Hence, throughout the years, Novozymes has been involved in a number of projects and events that include dialogue with customers, suppliers, NGOs, and local communities. For instance, Novozymes has regular meetings with the neighbors to the production sites and has been actively involved in a number of research projects and knowledge-sharing activities. This article is primarily based on Novozymes' involvement in two recent CSR projects:

- The "Purchasing with Decency" project. Novozymes has evaluated key suppliers on environmental performance for years. However, in 2003, the company launched the "purchasing with decency" project, which involved the development of a survey-based supplier self-evaluation on labor standards and human rights. The evaluation is based on international conventions and principles, and covers issues such as freedom of association, health and safety, child labor, nondiscrimination, and working hours. The evaluation concerns all key suppliers of raw materials (corresponding to approximately $80 \%$ of the total raw material costs).

- The "Genius" project. Genius was a three-year (2001-2004) educational project launched by Novozymes, Novo Nordisk, and the Danish Society for Nature Conservation. The aim of the project was to stimulate classroom discussions among students aged 14 to 18 around genetic engineering and the associated moral and ethical questions. The project resulted in a communication package including a website (www.geniusweb.dk), a magazine, a role-play card collection, and a TV show on the Danish National Broadcast System. The communication package includes factual information on genetic engineering, a history of important events in relation to this technology, and the attitudes and opinions of a wide range of stakeholders, including schoolchildren, politicians, scientists, and NGOs. When the project was finalized in 2003, all participants were invited to a seminar to evaluate the process and the results.

\section{Conclusions}

CSR is a broad subject which leads to a variety of opinions and can be considered in a number of different ways. CSR has gained in prominence in recent years. It has also changed in nature as different issues have become more prominent. We have considered these changes and looked in particular at environmental issues and the way in which the effects and associated costs can be externalized away from the company itself. CSR is now generally considered to be an integral part of strategy for any organization and built into the strategic planning process. There are many perceived benefits to an organization from this. Governance also is an integral part of this process. Globalization has an enormous effect on society and business life which can be manifest in a number of different ways. So business life needs more regulation and proper and socially responsible behavior than before. In this paper we have shown the relationship between CSR and globalization. We pointed out that the relationship between business failure/ scandals increased after the globalization, and social responsible behavior.

\section{REFERENCES}

[1] Carroll A B (1979); A three-dimensional conceptual model of corporate performance; Academy of Management Review 4 (4), 497 505

[2] Dahl R A (1972); A prelude to corporate reform; Business \& Society Review, Spring 1972, 17-23

[3] Friedman M (1970); The social responsibility of business is to increase its profits; New York Times 13 September

[4] Hetherington J A C); Corporate Social Responsibility Audit: A Management Tool for Survival; London; The Foundation for Business Responsibilities

[5] Crowther D ; Limited liability or limited responsibility; Perspectives on Corporate Social Responsibility; Aldershot; Ashgate; pp $42-58$

[6] Ortiz-Martinez E \& Crowther D (2006); Harvard Deusto Finanzas y Contabilidad, No 71 pp 2-12

[7] Paine T (1792); The Rights of Man (many editions)

[8] Rousseau J-J (1762); The Social Contract, Or Principles of Political Right (many editions)

[9] Blowfield M, J. G. Fryna, “ critical perspectives on Corporate Social Responsibility in developing world”, International Affairs 8 , 99 499-513

[10] Cramer J. (2002), "From Financial to Sustainable Profit", Corporate Social Responsibility and Environmental Management, 9, pp. 99-106.

[11] Dower N. (2004) "Global Economy, Justice and Sustainability" Ethical Theory and Moral Practice 7: pp. 399-415.

[12] Mcguire,J.B, A. Sundgren, "Corporate social responsibility and firm financial performance", Academy of Management, Vol. 31, No, 4, 854-872. 
[13] Scherer, A. G., G. Palazzo (2008), "Globalization and corporate social Responsibility” The Oxford Handbook of Corporate Social Responsibility Eds

[14] J. Moon, D. Siegel Oxford University Press 2008 (forthcoming)

[15] Selznick N (1957); Leadership in Administration: A Sociological Interpretation; Evanston, Ill; Row, Peterson.

[16] Wrighta, R. W, H. Etemad (2001), SMEs and the Global Economy, Journal of International Management, 7, pp 151-154

[17] Agrawal A \& Knoeber C R (1996); Journal of Financial and Quantitative Analysis, 31 (3), 377-398

[18] Aras G (2008); in D Crowther \& N Capaldi (eds), Ashgate Research Companion to Corporate Social Responsibility; Aldershot; Ashgate; pp 87-96

[19] Aras G \& Crowther D (2008); Exploring frameworks of corporate governance;), Culture and Corporate Governance; Leicester SRRNet; pp 3-16

[20] McCoy C S (1985); Management of Values: The Ethical Difference in Corporate Policy and Performance; Marshfield, Mass; Pitman

[21] Millstein. I.M. and MacAvoy. P.W.(2003); The Active Board of Directors and Performance of the Large Publicly Traded Corporation; 8 (5), 1283-1322

[22] Smith T (1992); Accounting for Growth; London; Century Business

[23] Van den Berghe, L.(2001), "Beyond Corporate Governance", European Business Forum, Issue 5, Spring.

[24] Novozymes, Benchmarking (Novozymes, 2005). www.novozymes.com

[25] Novozymes, Novozymes No. 1 for Sustainability for the fifth time; Novozymes, Novozymes in top twenty of sustainable business stocks, 2005).

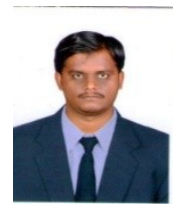

SP. Harish is doing his master degr in Public Relations from Sri-Venkateshwara University, Tirupathi, India. He already completed his masters in Business Administration and also bachelors in Mass Comunications. His research interests are in Corporate Social Responsibilities, Public Relations, Advertising and Cyber Laws.

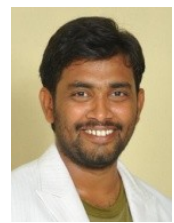

SP. Santhosh has received his master degree in Computer Science department specialized in Computer Networks and Information Security from JNTU, Hyderabad, India. Has Published many papers in various journals. His research interests include Public Relations, Network Security, Cloud Security, Information Security and Ethical Hacking. 